\title{
Foreign Language Pre-Service Teachers' Attitudes Towards Integrated Technology
}

\author{
https://doi.org/10.3991/ijet.v15i23.18797 \\ Jesus García Laborda ${ }^{(凶)}$ \\ Universidad de Alcalá, Alcalá de Henares, Spain \\ jesus.garcialaborda@uah.es \\ Valeska Concha Díaz \\ Universidad de Valencia, Valencia, Spain \\ Eva Jechimer Ramírez \\ Universidad de Alcalá, Madrid, Spain
}

\begin{abstract}
The COVID-19 pandemic worldwide evidenced the need to revise and strengthen the current perspective of the role of technology in nontechnology-based classes. The current situation requires the revision of practices and basic knowledge of computer literacy and use. Traditionally, technology in the process of language learning has been considered anecdotical. As a result, many teachers do not have the necessary skills to implement proper technology-supported classes. Being that the case at Universidad de Alcalá (Spain), we looked at the students' needs in integrating a number of different applications in the classroom in order to provide them with additional technological skills. Twenty-two pre-service teachers enrolled in the College of Education prepared a whole package of applications for computer and mobile phones by working cooperatively. This paper looks at their attitudes towards technology learning and implementation. A Likert-scale questionnaire was developed to assess their attitudes. Results indicated that students do not evidence as much interest as expected despite their limited ability to implement the package.
\end{abstract}

Keywords - Technology; blogs; social media; teacher education; bilingual education

\section{Introduction}

Developments in every field have been increasing with the innovations brought by technology. Mobile supported applications have taken their place in many areas such as commerce, business, education and industry [30]. The effectiveness of technologysupported education and teaching in the field of education is supported by many studies. Teachers have become aware of their needs to be competent users and creative designers of technology-based activities in the first semester of 2020 when people from most countries in the world remained locked down due to the COVID-19 
pandemic. While the effects of this pandemic are to be studied further, there is a necessity to reconsider the role of economics but even more of education and especially educational technology. Some studies have pointed out the interest and positive attitudes of young teachers towards the development and use of certain contents through technology, however, its use still remains anecdotical. These attitudes have led to a discontinuous use of technology in the classroom [1]. While laptops and tablet PCs have taken a significant role in the classroom as sources of information, working tools and internet access, the presence of other technologies such as software for educational purposes have remained very limited. It is true that students today have developed a significant capacity and perceptive in the use of applications and platforms but their interest towards the use of educational applications still remains unclear.

In such a context, this paper aims to look at the students' attitudes towards the use of integrative blogs where a number of different tools are combined such as applications, LinkedIn, communication tools, etc. To do so, a questionnaire was designed and delivered to a group of teachers in training at the University of Alcalá at the end of the first semester of the 2019-2020 academic year just before the COVID19 pandemic.

\section{$2 \quad$ Literature Review}

Blogs have been an educational resource for many years [2, 3, 4]. However, this does not necessarily mean that their educational use might not be new for different students [5, 6]. In fact, the term new technologies are totally true since new technologies are always new for the students who begin to use them for the first time) [7]. This might not be always around the same age [8,9]. Many students get the experience to use blogs or e-portfolios at different educational stages whether primary, secondary or higher education. Thus, it is not unusual to begin to use communication tools as late as in higher education [10]. The question is when it the correct time to start to use such tools and, even more important, what their final purpose is. A number of researchers of blogs have looked at the opportunities of using blogs in the classroom and even for the hybrid class [11, 12] but few have looked at their own prospective applicability $[13,14]$. Overall, many tend to observe the blogs as a product rather than as a process [15] instead of a means to create educational communities [16] despite the long standing tradition that blogs serve as formative assessment tool [17, 18] especially in writing [19, 20, 21] and reading [22, 23], although [24] also states that this sort of multimedia facilitates the integration of listening learning objects. In general, blogs are considered as a reflection tool $[25,26$, 27, 28] for professionals in Language Teaching - and obviously many other fields[28].

In this given scenario, it was the interest of this research to observe whether after five years of using blogs in the pre-service classroom at Universidad de Alcalá (20142019 ) it was just about the time to close the technical innovation due to the normalization of blogs by higher education students. In order to do so, students should 
recognize that blogs do not bring any interesting assets to their teaching and that their use has become normalized in education beyond their use as an e-portfolio. Thus, these were the main research questions for this research:

a) Do students believe that blogs do not represent an adequate tool to develop their linguistics skills?

b) Do students consider that blogs are worth to be done in university?

c) Do they consider that blogs are adequate for their future teaching?

\section{$3 \quad$ Methodology}

\subsection{Participants and procedure}

The sample comprised of twenty-two students from foreign language (English) specialization the College of Education of Universidad de Alcalá at Guadalajara representing about $50 \%$ of all the students in such major in the college. The average age was 22.25 (range $=21-25, \mathrm{SD}=2.20$ ). Most students were female $(86.4 \%)$ due to the fact females are the predominant sex at the College of Education of Universidad de Alcalá and the sample was considered representative of the whole college. Participants completed a questionnaire during class time. Participation was anonymous and voluntary, and data collection followed the Ethical Guidelines applicable to Research with Humans at Universidad de Alcalá. Before completing the questionnaire, participants gave their consent to use these data by using pseudynms.

\subsection{Instruments}

The research used a Spanish-language revised version of the Course Blog Attitude Questionnaire (CBAQ) [29]. Participants rated fifteen items on 4-point scales due to the limited sample (four-point Likert-type scale ranging between 1 (e.g., strongly disagrees) and 4 (e.g., strongly agree)) and one more distractor ("I believe this questionnaire is funny"). The questionnaire addressed three subscales: 1) Questions related to previous use and knowledge (questions 1, 2 -blue-);2) Difficulties in developing and integrating the different sections of the blog and other parts such as the apps, videos, etc. (questions3, 5, 6, 10, 11, 13, 14 - brown-; and 3) Prospective use in the students' career (questions 4, 7, 8, 9, 12, 15-green-). 
Table 1. Descriptive statistics

\begin{tabular}{|c|c|c|c|c|}
\hline Question & $\mathbf{N}$ & Mean & Median & Standard deviation \\
\hline I had developed blogs before taking this course & 22 & 2,36 & 2 & 1,329 \\
\hline $\begin{array}{l}\text { The apps that I have included have been used in the } \\
\text { process of the project in class or before it }\end{array}$ & 21 & 2,76 & 3 & 0,889 \\
\hline $\begin{array}{l}\text { Creating a blog with online tools (blogger or others) is } \\
\text { easy }\end{array}$ & 21 & 3 & 3 & 0,707 \\
\hline $\begin{array}{l}\text { I think this work will be useful for my future performance } \\
\text { as a teacher }\end{array}$ & 22 & 3,14 & 3 & 0,640 \\
\hline $\begin{array}{l}\text { Through the blog, I have learned vocabulary and } \\
\text { structures of written English }\end{array}$ & 22 & 2,91 & 3 & 0,684 \\
\hline $\begin{array}{l}\text { Through the blog, I have learned about the content } \\
\text { developed in it }\end{array}$ & 22 & 3,36 & 3 & 0,581 \\
\hline $\begin{array}{l}\text { My blog could be an interesting tool to exchange } \\
\text { information }\end{array}$ & 22 & 3,45 & 3,5 & 0,596 \\
\hline $\begin{array}{l}\text { The blog can be an interesting tool for my elementary } \\
\text { students }\end{array}$ & 22 & 3,68 & 4 & 0,568 \\
\hline $\begin{array}{l}\text { The apps I have included would be very useful in the } \\
\text { future }\end{array}$ & 22 & 3,18 & 3 & 0,664 \\
\hline Blogs have helped me to work as a team & 22 & 3,45 & 4 & 0,671 \\
\hline Our coordination in the project has been good & 22 & 3,50 & 4 & 0,859 \\
\hline I think my blog could be used to learn outside of class & 22 & 3,45 & 3 & 0,510 \\
\hline Blogs allow better adaptation to teaching & 22 & 3,32 & 3 & 0,477 \\
\hline The work with the videos has been interesting & 22 & 3,59 & 4 & 0,503 \\
\hline $\begin{array}{l}\text { I believe that the use of blogs is appropriate to invert the } \\
\text { class (give information to students that there is usually no } \\
\text { time to see in class and discuss more) }\end{array}$ & 21 & 3,33 & 3 & 0,577 \\
\hline This survey is a lot of fun & 22 & 2,80 & 3 & 0,894 \\
\hline
\end{tabular}

\section{$4 \quad$ Results}

\subsection{Descriptive statistics}

As can be seen, Table 1 offers the central tendencies exposed in ordinal data, and one of the answers that has the most appreciation on the part of the group of participants, is the one that makes mention of how "blogs" are an interesting tool for primary school students, with an average of 3.68 out of 4 as the maximum rating, which means that teachers have a positive attitude about working with new learning strategies. There is a high evaluation of the questions that were asked to know how the work was done with the new tools that enhance the work with the students; among them they stand out as the work with the videos has been interesting for the teachers, answering a 3.59 , this is followed by the good assessment of the coordination that existed in the project, with a rating of 3.50 .

In the same way, the answers that refer to whether blogs have helped them to learn outside of class, whether they are considered an interesting tool for students and that if it has allowed them to work in a team, they are highly valued by the participants., 
since it is valued with a 3.50 out of 4 , which leads us to infer that blogs are a positive strategy in pedagogical work.

On the other hand, the responses that were least valued by the participants are those that are related to carrying out activities with new strategies, either in the development of blogs before taking the course, as if the apps that the participants have used were used in the process of the project in classes or before it, having a valuation of 2.36 and 2.76 respectively.

Table 2. Score results in the survey

\begin{tabular}{|c|c|c|c|c|c|}
\hline Question & Option 1 & Option 2 & Option 3 & Option 4 & Lost \\
\hline I had developed blogs before taking this course & 40,9 & 13,6 & 13,6 & 31,8 & \\
\hline $\begin{array}{l}\text { The apps that I have included have been used in the } \\
\text { process of the project in class or before it }\end{array}$ & 9,1 & 22,7 & 45,5 & 18,5 & 4,5 \\
\hline $\begin{array}{l}\text { Creating a blog with online tools (blogger or others) is } \\
\text { easy }\end{array}$ & & 22,7 & 50 & 22,7 & 4,5 \\
\hline $\begin{array}{l}\text { I think this work will be useful for my future } \\
\text { performance as a teacher }\end{array}$ & & 13,6 & 59,1 & 27,3 & \\
\hline $\begin{array}{l}\text { Through the blog I have learned vocabulary and } \\
\text { structures of written English }\end{array}$ & & 27,3 & 54,5 & 18,2 & \\
\hline $\begin{array}{l}\text { Through the blog I have learned about the content } \\
\text { developed in it }\end{array}$ & & 4,5 & 54,5 & 40,9 & \\
\hline $\begin{array}{l}\text { My blog could be an interesting tool to exchange } \\
\text { information }\end{array}$ & & 4,5 & 45,5 & 50 & \\
\hline $\begin{array}{l}\text { The blog can be an interesting tool for my elementary } \\
\text { students }\end{array}$ & & 4,5 & 22,7 & 72,7 & \\
\hline $\begin{array}{l}\text { The apps I have included would be very useful in the } \\
\text { future }\end{array}$ & & 13,6 & 54,5 & 31,8 & \\
\hline Blogs have helped me to work as a team & & 9,1 & 36,4 & 54,5 & \\
\hline Our coordination in the project has been good & 4,5 & 9,1 & 18,2 & 68,2 & \\
\hline I think my blog could be used to learn outside of class & & & 54,5 & 45,5 & \\
\hline Blogs allow better adaptation to teaching & & & 68,2 & 31,8 & \\
\hline The work with the videos has been interesting & & & 40,9 & 59,1 & \\
\hline $\begin{array}{l}\text { I believe that the use of blogs is appropriate to invert } \\
\text { the class (give information to students that there is } \\
\text { usually no time to see in class and discuss more) }\end{array}$ & & 4,5 & 54,5 & 36,4 & 4,5 \\
\hline This survey is a lot of fun & 4,5 & 31,8 & 31,8 & 22,9 & 9,1 \\
\hline
\end{tabular}

The distribution of the responses was made according to the results of each item and they were marked from 1 to 4 where the participant presents an answer as; I disagree, 2 slightly agree, 3 agree and 4 strongly agree.

For question number 1 , it can be seen that the response trend has been developed in that $40.9 \%$ of the participants disagree with the development of blogs before taking the course, followed by $31.8 \%$ who are Accordingly, which means that they had carried out the creation of blogs and $13.6 \%$ disagreed. In response 2 , which aims to reveal if the apps that were included have been used in the project process in class or before, $45.5 \%$ of the participants agree, followed by $22.7 \%$ who disagrees. While only $9.7 \%$ disagree, in this answer there is a participant who does not respond, equivalent to $4.5 \%$ of the total sample. 
Regarding 3, 4, 5, 6 and 7 responses, among which option 3 showing that they agree with what was consulted, the same case occurs for option 1 , which means that no participant is not according to what is being asked. In the case of questions 6 and 7, we can visualize how the participants consider it relevant that through the blog they have learned about the content developed in it and how blogs could be an interesting tool for exchanging information, since for both questions, the Option 4 has a higher percentage of acceptance, with $40.9 \%$ and $50 \%$ respectively. In the case of question 8 , which aims to reveal if the blog can be an interesting tool for my elementary school students, there is a high assessment from 16 participants who strongly agree with it, corresponding to $72.7 \%$ followed by $22.7 \%$ who agree and only $4.5 \%$, that is, a single participant, who disagrees a little. The question about whether the apps that I have included would be very useful in the future, has a positive evaluation from the participants, since $54.5 \%$ of the respondents consider that they agree that the apps would be useful in the future, as well as $31.8 \%$ who stated that they strongly agree. $13.6 \%$ disagree and there are no participants who indicate that they disagree. What happens with the answer to the question that tries to reveal if the blogs have served the participants to work as a team, is that $54.5 \%$ indicate that they very much agree with it, followed by $36.4 \%$ who stated agree. This means that $90.9 \%$ of those surveyed consider that these strategies contribute to teamwork. When asked if coordination in the project has been good, there is more heterogeneity of responses, since $68.2 \%$ of the participants agree with it, followed by 18.25 who agree, $9,1 \%$ disagree and only $4.5 \%$ disagree with the coordination carried out.

At the time of asking participants about whether their blog could be used to learn outside of class, $54.5 \%$ of the answers indicate that they agree with the usefulness it could have outside the classroom, followed by $45.5 \%$ who indicate that they strongly agree with this. This means that the possibility of using them outside of class is highly valued. In the case of the answer that tries to find out if blogs allow for a better adaptation of teaching, there are $68.2 \%$ of the participants who consider that they agree with it, followed by the remaining $31.8 \%$ who strongly agree, this positively positions blogging as a strategy that helps adapt teaching. When the participants were asked to assess whether the work with videos has been interesting, $59.1 \%$ of them stated that they agreed with the statement, followed by $40.9 \%$ who agreed. In the same way, when asked to assess whether the use of blogs is adequate to invest the class (give information to students that there is usually no time to see in class and debate more), $54.5 \%$ agree, followed by $36.4 \%$ who strongly agree, $4.5 \%$ who disagree and do not respond.

\section{Interpretation and Conclusion}

This research was the result of the students' attitudes towards the use of a set of web 2.0 tools embedded in a blog. The main concern was whether it was interesting keeping on the teaching of blogs under the heading of the 2019-20 innovation project "UAH/EV1136 - Motivación en el aprendizaje de inglés a través de apps y redes sociales". As a response to the title, it was observed that students had a limited 
experience as designers of blogs (question 1) nor had they much previous learning or learning in class with apps and other social media (question 2). In relation to the difficulty and user experience with the blog, students believed the creation was rather adequate and led both to learning the content as well as improving their use of English especially in grammar and vocabulary (question 5). According to their responses blogs also helped them to develop cooperative skills (questions 10 and 11). Finally, the development of their own videos was considered positively.

Our last block of questions, which were most relevant to the research team intended to look at a prospective use of blogs in the classroom of Primary Education. Overall, students were positive but not as much as the research team would have expected. Except question 8, none of the means of the items of this block was higher than 3.5. This may mean that prospective teachers understand the value the possibility to integrate technology (especially blogs, of course) in the Primary classroom, significant doubts of whether students see blogs and the media used in the project as really powerful tools for their future as teachers.

In conclusion, the results shed a positive light in reference to the use of blogs for prospective teachers. Nothing seems to be old-fashioned until it has been experienced in education and, as a consequence, we understand that the teaching of blogs and the inclusion of social tools and apps in web 2.0 is still necessary. Students still rate these tools positively but not as much as the researchers thought it would be. The fact, that blogs have been in use for many years may not be a significant problem while the fact that students are used to read on online blogs may be the reason of little positive "surprise" and thus the fact that blogs and web 2.0 have been totally standardized in education.

\section{Acknowledgement}

The researchers would like to express their gratitude to the Universidad de Alcalá (Spain) for the support in the granting of the "UAH/EV1136 - Motivación en el aprendizaje de inglés a través de apps y redes sociales" (Motivation in the learning of English through apps and social networking) in the 2019-2020 that unfortunately was not finished due the lock down in Spain (March-July 2020). We would also like to thank Margarita Bakieva for her invaluable support in this and other projects run by the "Research on English Language Teaching: Skills, content, computers and assessment" of Universidad de Alcalá.

\section{$7 \quad$ References}

[1] Shana, Z. A., \& Abulibdehb, E. S. (2015). Engaging students through blogs: Using blogs to boost a course experience.International Journal of Emerging Technologies in Learning, 10(1): 30-38. http://doi.org/10.3991/ijet.v10i1.4240

[2] Arani, J. A. (2012). Teaching English medical writing in a blended setting. International Journal of Emerging Technologies in Learning, 7(4): 34-37. http://.doi.org/10.3991/ijet.v7 $\underline{\mathrm{i} 4.2253}$ 
[3] Kuimova, M. V., \& Zvekov, O. D. (2016). Blogs as a means to enhance writing skills in EFL classes. International Journal of Emerging Technologies in Learning, 11(4): 157-160. http://doi.org/10.3991/ijet.v11i04.5430

[4] Sulistyo, T., Mukminatien, N., Cahyono, B. Y., \& Saukah, A. (2019). Enhancing learners' writing performance through blog-assisted language learning. International Journal of Emerging Technologies in Learning, 14(9): 61-73. https://doi.org/10.3991/ijet.v14i09.9535

[5] Absalom, M., \& De Saint Leger, D. (2011). Reflecting on reflection: Learner perceptions of diaries and blogs in tertiary language study. Arts and Humanities in Higher Education: An International Journal of Theory, Research and Practice, 10(2): 189-211. http://doi.org. ezproxy.uned.es/10.1177/1474022210389141

[6] Haines, K., \& van Engen, J. (2013). Re-conceptualizing the ELP as a Web 2.0 personal language learning environment. Language Learning in Higher Education, 2(1): 129-144. http://doi.org.ezproxy.uned.es/10.1515/cercles-2012-0008

[7] Reinhardt, J. (2019). Social media in second and foreign language teaching and learning: Blogs, wikis, and social networking. Language Teaching, 52(1): 1-39.

[8] Cruz Rondón, E. J., \& Velasco Vera, L. F. (2016). Understanding the role of teaching materials in a beginners' level English as a foreign language course: A case study. PROFILE: Issues in Teachers' Professional Development, 18(2): 1-13.

[9] Durriyah, T. L., \& Zuhdi, M. (2018). Digital literacy with EFL student teachers: Exploring indonesian student teachers' initial perception about integrating digital technologies into a teaching unit. International Journal of Education and Literacy Studies, 6(3):, 53-60.

[10] García Laborda, J., \& Litzler, M. F. (2017). English for business: Student responses to language learning through social networking tools. ESP Today: Journal of English for Specific Purposes at Tertiary Level, 5(1): 91-107.

[11] Ceylan, V. K., \& Kesici, A. E. (2017). Effect of blended learning to academic achievement. Journal of Human Sciences, 14:1, 308-320

[12] Mnkandla, E., \& Minnaar, A. (2017). The use of social media in E-learning: A metasynthesis. International Review of Research in Open and Distributed Learning, 18(5): 227-248. https://doi.org/10.19173/irrodl.v18i5.3014

[13] Khan, A. (2017). Blog-based professional development of english teachers in mumbai: The potential of innovative practice under scrutiny. Australasian Journal of Educational Technology, 33:4, 88-106. http://doi.org.ezproxy.uned.es/10.14742/ajet.2784

[14] Çetin, N. M., Telli, E., Daghan, G., \& Akkoyunlu, B. (2019). Determining reflectivity levels of prospective teachers through blogs. International Online Journal of Education and Teaching, 6(3): 582-596. http://iojet.org/index.php/IOJET/article/view/500

[15] Hurn, K. (2012). The impact of social software in product design higher education. Design and Technology Education, 17(2): 35-48.

[16] Cheng, J. (2008). How macromedia used blogs to build its developers' communities: A case study. Performance Improvement Quarterly, 21(3): 43-58. http://doi.org.ezproxy.un ed.es/10.1002/piq.20030

[17] Di Gregorio, L., \& Beaton, F. (2019). Blogs in the modern foreign languages curriculum. A case study on the use of blogging as a pedagogic tool and a mode of assessment for modern foreign languages students. Higher Education Pedagogies, 4(1): 406-421. http:// doi.org.ezproxy.uned.es/10.1080/23752696.2019.1644660

[18] Cartner, H., \& Hallas, J. (2020). Aligning assessment, technology, and multi-literacies. ELearning and Digital Media, 17(2): 131-147. http://doi.org.ezproxy.uned.es/10.1177/20 $\underline{42753019899732}$ 
[19] Akdag, E., \& Özkan, Y. (2017). Enhancing writing skills of EFL learners through blogging. Reading Matrix: An International Online Journal, 17(2): 79-95. Retrieved from https://search-proquest-com.ezproxy.uned.es/docview/1969007245?accountid=14609

[20] Helm, F., \& Dooly, M. (2017). Challenges in transcribing multimodal data: A case study. Language Learning \& Technology, 21(1): 166-185.

[21] Giannikas, C. N. (2019). Enhancing literacy and collaborative skills through blogging: The teenage language learner. Research-publishing.net.

[22] Yakut, A. D., \& Aydin, S. (2017). An experimental study on the effects of the use of blogs on EFL reading comprehension. Innovation in Language Learning and Teaching, 11(1): 116. http://dx.doi.org.ezproxy.uned.es/10.1080/17501229.2015.1006634

[23] Arndt, H. L., \& Woore, R. (2018). Vocabulary learning from watching YouTube videos and reading blog posts. Language Learning \& Technology, 22(3): 124-142. https://doi.org/ $10125 / 44660 /$

[24] Sejdiu, S. (2017). Are listening skills best enhanced through the use of multimedia technology. Digital Education Review, 32: 60-72.

[25] Yang, S. (2009). Using blogs to enhance critical reflection and community of practice. Educational Technology \& Society, 12(2): 11-21.

[26] Jackling, B., Natoli, R., Siddique, S., \& Sciulli, N. (2015). Student attitudes to blogs: A case study of reflective and collaborative learning. Assessment \& Evaluation in Higher Education 40(4): 542-556.http://dx.doi.org.ezproxy.uned.es/10.1080/02602938.2014.9319 $\underline{26}$

[27] Ferguson, J. L., Makarem, S. C., \& Jones, R. E. (2016). Using a class blog for student experiential learning reflection in business courses. Journal of Education for Business, 91(1): 1-10. http://dx.doi.org.ezproxy.uned.es/10.1080/08832323.2015.1108279

[28] Tajeddin, Z., \& Aghababazadeh, Y. (2018). Blog-mediated reflection for professional development: Exploring themes and criticality of L2 teachers' reflective practice. TESL Canada Journal, 35(2): 26-50. Retrieved from https://search-proquest-com.ezproxy.uned. es/docview/2228649887? accountid=14609

[29] Shahsavar, Z., \& Tan, B. H. (2012). Developing a questionnaire to measure students' attitudes toward the course blog. Turkish Online Journal of Distance Education, 13(1): 200-210

[30] Dirin, A., Laine, T.., Alamäki, A., (2018). Managing Emotional Requirements in a Context- Aware Mobile Application for Tourists. Int. J. Interact. Mob. Technol. 12, 177. https://doi.org/10.3991/ijim.v12i2.7933

\section{Authors}

Jesus García-Laborda PhD in English Philology, Universidad Complutense de Madrid (2000); European Doctor of Education (Teaching of Language and Literature). Universidad Complutense de Madrid (2010); Master's in ESL - U. of Georgia, 1992. Master's in Language and Comparative Literature - U. Wisconsin. Currently works as the Dean of the College of Education of the University of Alcala de Henares. He teaches Didactics of English as a Foreign Language. He is Academic bureau member of Franklin Institute. His research is related to Applied Linguistics in the field of Computer-assisted Second Language Learning. He has participated in various national and international research projects on the use of technology in education and assessment related to learning of second language and English for Specific Purposes. Mail: jesus.garcialaborda@uah.es Researcher ID: E-1797-2012 


\section{ORCID: http://orcid.org/0000-00 03-0125-4611}

Valeska Concha Díaz. has a degree in Education, a Kindergarten Educator from the University of Concepción. Master in Policy, Management and Direction of educational organizations, graduated from the University of Valencia in September 2018. Along with her work as a kindergarten educator in different Chilean Schools and Colleges, she has served as a full professor in the education department of the Catholic University of La Santísima Concepción, where she also held the position of Supervisor of Practices within the Career of Higher University Technician of Early Childhood Education. Currently, she is studying a Doctorate in Education based on Research and Diagnostics in Education (MIDE) at the University of Valencia, Spain. Mail: vale.concha.cd@gmail.com. ORCID: https://orcid.org/0000-0002-6425-8866

Eva Jechimer Ramírez is an Assistant Professor at the Faculty of Education of the University of Alcalá. She teaches English as a Foreign Language IV: Skills in Written and Oral Expression and Content and Language Integrated Learning (CLIL). She is also a Primary Teacher in a bilingual school in the Community of Madrid. This combination provides a valuable perspective to her investigation in the field of second language teaching (English) in CLIL contexts. Her experience in the Primary classroom led her to the need to change the methodology of teaching future Primary teachers. Mail: eva.jechimer@uah.es

Article submitted 2020-09-21. Resubmitted 2020-09-30. Final acceptance 2020-10-01. Final version published as submitted by the authors. 